\title{
1. 40 years of China's reform and development: How reform captured China's demographic dividend
}

\section{Cai Fang, Ross Garnaut and Ligang Song ${ }^{1}$}

China's reform, opening-up and resultant economic growth in the past 40 years provide a new constellation of experience we can study to understand the nature of modern economic growth. This chapter describes the process of reform and opening-up of the economy, and its nexus to accelerated economic growth. It describes and provides some data on the experience of trade and growth over the past 40 years. It sketches some of the main elements of reform, changes in incentives that have driven economic growth, changes in economic structure that have followed and the rising role of China in the global economy. It highlights new challenges that China faces after 40 years of reform.

\section{Introduction}

The eleventh Central Committee of the Communist Party of China (CPC) held its third plenum from 18 to 22 December 1978. This meeting reestablished an older $\mathrm{CPC}$ ideological line of 'seeking truth from facts'. It decided to shift the focus from political movement to economic development. This laid the foundation for reform and opening-up.

In the winter of the same year, Xiaogang, one of the poorest villages in Fengyang county in Anhui province, abandoned its collective brigade production structure and became the pioneer for contracting collectively owned land to households. Such a practice—later known as the household responsibility system (HRS)—spread nationwide in the early 1980s and replaced the people's commune system that had existed for a quarter of a century. This was the first break in the planned economy.

China initiated the change from central planning to mainly market exchange simultaneously with opening up to international trade and investment. Domestic economic development and participation in economic globalisation have marched forward hand in hand. ${ }^{2}$

1 We thank Xiaoying Wang for her help in assembling the data for most of the figures used in this chapter.

2 The International Monetary Fund (IMF 2006: 4) considered 1979 the start year for China's economic take-off. 
Deng Xiaoping was a source of, sponsor within the party for and, for two decades, the protector of China's reform and opening-up policy. In July 1979, under Deng's influence, the central government decided to establish 'special export zones', later called special economic zones (SEZs), in Shenzhen, Zhuhai and Shantou in Guangdong province and Xiamen in Fujian province. This signalled the start of China's opening to the outside world.

This experiment was extended to 14 large cities in coastal areas in 1984, the newly established province of Hainan in 1988, and a host of cities along the Yangtze River and interior border cities in the early 1990s. These domestic steps to open to the international economy were extended to global institutions with China's application to resume the status of a contracting party to the General Agreement on Tariffs and Trade (GATT) in 1986 and its accession to the World Trade Organization (WTO) in 2001.

China's reforms are 40 years old. The Master said: 'At 40, I perceived truth and doubts ceased.' ${ }^{3}$ A wealth of empirical materials accumulated over 40 years confirms the wisdom of internationally oriented market reform and helps us to draw theory from experience to guide future reform.

China's reform and opening-up is in the process of delivering to 1.4 billion Chinese people the fruits of the most consequential socioeconomic change and institutional innovation in human history. If it is able to maintain momentum in reform at a more challenging time, it is likely to deliver high-income status to the Chinese people by the early 2020 s-more than doubling the number of people living in countries with that status (Figures 1.1 and 1.2).

China's reform and opening-up has both universal and unique features.

This chapter seeks to answer the following questions: How and why did China miss the opportunity of catching up with the developed countries during its planned economy era? How was China's economic growth enhanced by removal of institutional constraints, factor accumulation and improvements in resource allocation? At the current stage of China's development, with upper-middle incomes, what new approaches are required for China's growth engine to gain new momentum, and to drive China into the ranks of the high-income countries?

3 This is an oft-recounted quotation in Confucian Analects; the English translation is quoted from Jin (2005: 4). 


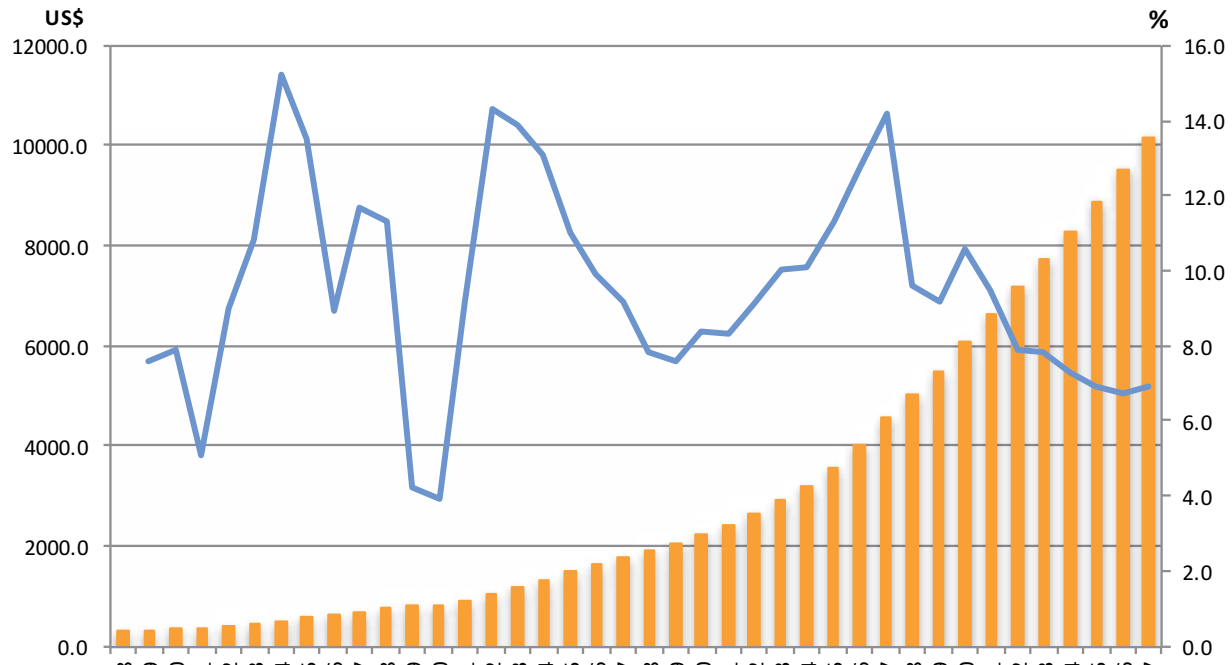

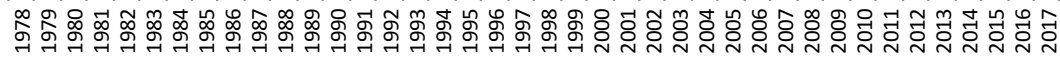

GDP (billion US\$ at 2010 prices)

GDP growth rate (\%)

Figure 1.1 China's GDP (LHS) and growth rate (RHS), 1978-2017

Sources: UNCTAD Statistics (unctadstat.unctad.org/EN/).

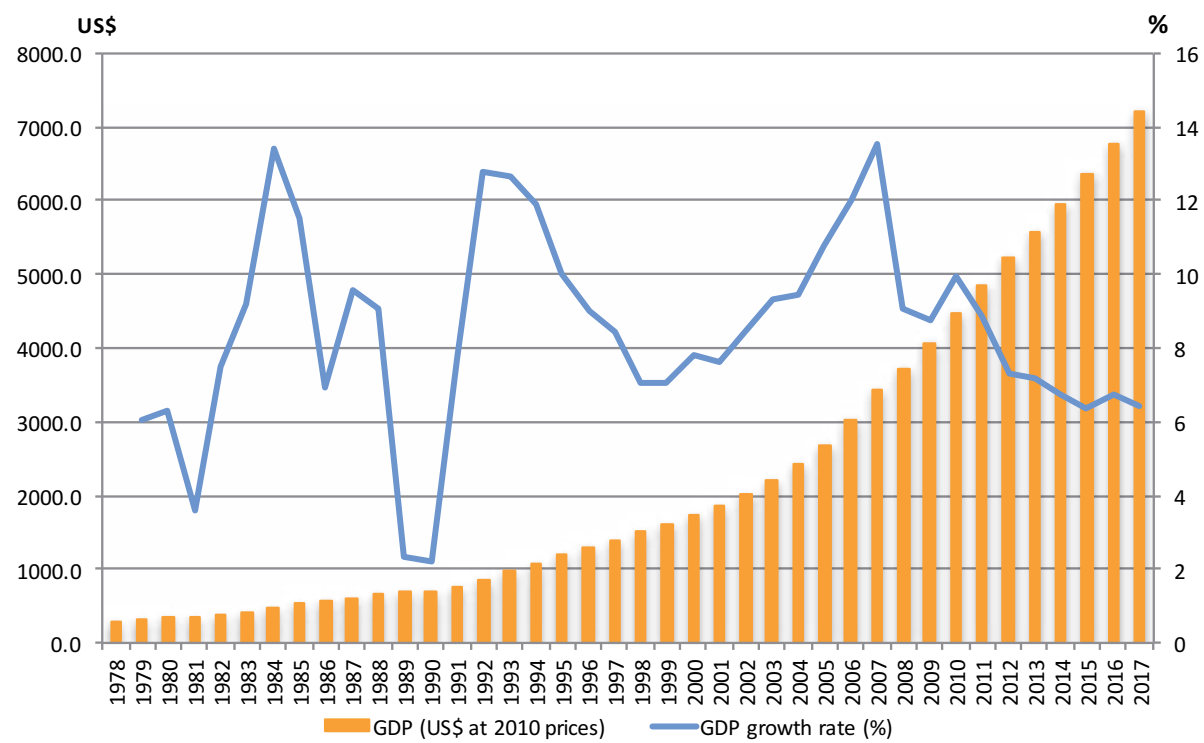

Figure 1.2 China's GDP per capita (LHS) and growth rate (RHS), 1978-2017 Sources: UNCTAD Statistics (unctadstat.unctad.org/EN/). 


\section{Missed opportunity of convergence in the planning era}

In 1980, China ranked near the lowest in the world in gross national income per capita. It ranked much higher in terms of major human capital indices, and about the middle for average years of schooling for the population aged 25 and older and for life expectancy at birth (Cai 2015a: 40).

Although per capita income was very low, the capital stock and rate of capital accumulation were much higher, and China had demonstrated strong capacity to mobilise capital. In the period 1953-78, the average investment rate was 29.5 per cent-significantly higher than the world average and most developing economies (Lin et al. 2003: 71-4).

The planned economy lacked the necessary institutional conditions for efficient resource allocation and work incentives. Cross-nation studies and China's experience show that rejection of the market mechanism under planning causes inefficiency in resource allocation. Lack of autonomy in business decisions and lack of incentives depress work effort.

Through the planning period, high rates of capital accumulation and rapid increases in the labour force did not lead to commensurate rates of economic growth because productivity performance was low. Resource misallocation distorted the industrial structure. Appropriate technology was not applied in economic activity.

Through the early years of the People's Republic of China and the planning system, beginning in the early 1950s, China moved from the demographic combination of a high birth rate, high mortality rate and low population growth to one of a high birth rate, low mortality rate and high population growth. The latter state, with rapid growth of the population and labour force, has often been part of a process of economic involution. ${ }^{4}$ The result has been a dual economy characterised by a labour surplus in agriculture (Lewis 1954).

In the late 1960s, fertility began to decline, bringing down population growth. Population conditions more conducive to economic growth-with a potential demographic dividend-emerged. The accumulated labour surplus provided potential comparative advantage in the production of labour-intensive goods and services. The demographic dividend would magnify the benefits. Linked with open international trade, this could have spurred high-speed economic growth.

4 Economic history shows that near the end of the Malthusian poverty trap as a stage of development, many countries began to experience a process of economic involution characterised by accumulation of massive surplus labour in agriculture, followed by entry to the stage of dual-economy development conceptualised by Lewis (1954). 
This opportunity was not taken, because a comparative advantage-defying rather than a comparative advantage-following strategy was adopted. ${ }^{5}$

China sought to promote industrialisation and to catch up with the advanced countries by mobilising resources and allocating them through central planning without international trade.

China's planned system had three elements: the macropolicy environment, planned resource allocation and micromanagement institutions (Lin et al. 2003). The development strategy gave impetus to industrialisation, but the economic system that emerged had severe defects.

The macropolicy environment gave priority to heavy industry in the hope of speeding up capital accumulation and industrialisation. The industrial structure deviated far from China's comparative advantage and a disproportionate part of output was allocated to investment rather than to consumption.

The highly centralised planning system denied a role for markets. It was suitable for implementing the economic plan, but led to an imbalance between the supply of and demand for products and a failure to allocate resources to their most valuable uses. Total factor productivity (TFP) declined and dragged down economic growth.

Micromanagement institutions characterised by nationalisation of industry and collectivisation of agriculture were arranged to carry out the national plan and match the planning system. Lacking operational autonomy and work incentives, the production units - state-owned enterprises (SOEs) and people's communesoperated extremely inefficiently. This contributed to the decline in TFP.

The Chinese economy in the planning period was almost completely isolated from the world economy. In 1978, the share of exports plus imports in gross domestic product (GDP) was only 9.7 per cent. Primary products (agricultural products and raw materials) contributed more than half of the low level of exports. There was no direct investment. Maddison (2007: 102) estimates the annual average growth rate of GDP in the period $1952-78$ was 4.4 per cent in purchasing power parity (PPP) terms. This was below the average for developing countries.

Spence (2011: Pt 1) argues that the global economy started an era of convergence about 1950 . Since the 1950s, a number of initially poor economies have caught up with the developed countries. Maddison's data show that in the period 1952-78, the annual GDP growth rate was 4.3 per cent in the rich countries, 4.9 per cent in 'others' and 4.6 per cent for the world average.

5 For the definition of the two contrasting strategies, see Lin and Wang (2010); for analysis of the adoption of the Chinese strategy in the late 1950s, see Lin et al. (2003). 
China's relative performance was worse in per capita terms, because its population growth was higher. In 1952, China’s per capita GDP was US\$538 in 1990 prices. This was 8.7 per cent of the average of the rich countries, 46.5 per cent of the 'others' and 23.8 per cent of the world average. By 1978, China's per capita GDP (US\$978 at constant price) had fallen as a percentage of each of those three groups, to 6.8 per cent, 42.1 per cent and 22.1 per cent, respectively.

We can conclude that in the first three decades of the People's Republic, China not only missed the chance to catch up with the developed countries, but also fell further behind the rest of the world.

Let us examine how the planned economy led to inefficient resource allocation.

In $1952,82.5$ per cent of the labour force worked in agriculture. That was potentially a source of surplus labour for modern economic development.

In the mid-1960s, the population dependency ratio - the ratio of the working aged to the dependent population-began to fall, overwhelmingly from the decline in the proportion of people younger than working age. From this time, China enjoyed a demographic dividend that theoretically could have been translated into accelerated economic growth.

The Lewis model and its application to developing countries (Lewis 1954; Cai 2016) show that an abundant labour force not only delivers labour supply, but also helps to maintain a high savings rate, avoids diminishing returns to capital and raises allocative efficiency as labour is transferred from agriculture to other sectors. The planning model stopped China from enjoying all these benefits. The share of agricultural labour was still 74.5 per cent in 1977.

Zhu (2012) has developed a lower estimate than Maddison of average GDP growth: 2.97 per cent in the period 1952-78. The labour force grew at 3.63 per cent, and increases in capital stock and human capital made large positive contributions. The decline in TFP dragged growth down by 72 per cent from what it would otherwise have been.

The 'Great Leap Forward' and the Cultural Revolution were the most disastrous episodes during the planning period. We can presume that losses during these catastrophes contributed much of the underperformance of the planning period, although the extent of the contribution is difficult to estimate. Kwan and Chow (1996) attempt an estimate. 


\section{Impact of reform and opening-up}

Adequate capital accumulation and efficient allocation of physical and human capital are prerequisites for successful economic development. Reform of a planned economic system to provide these prerequisites requires at least three conditions to be met. First, the reform should bring benefits to at least one major group of participants, to provide political support. Second, these benefits cannot be at the expense of any other substantial groups in society - that is, the reform has to deliver a 'Pareto improvement'. Third, the reform should start in a key area to transmit its momentum to other areas of the system.

The early reforms in rural China characterised by the introduction of the HRS and the abolition of the people's communes met these conditions rather perfectly. The HRS was at first accepted for individual cases and, as early as the late 1970s, was piloted in some poor, remote areas and eventually encouraged nationwide by the central government. By the end of 1984, all production brigades and 98 per cent of households in rural China had adopted the HRS. The people's commune system was officially abolished at this time. This reform immediately improved incentives for agricultural production by granting farmers autonomy over operations and rights to profits from more efficient use of their land and labour, which gave them incentives to raise productivity.

In the period 1978-84 - the years of transition from the people's communes to the HRS - grain yield per unit area increased by 42.8 per cent, total output of grain increased by 33.6 per cent and real agricultural value added increased by 52.6 per cent. Lin (1992) shows that 46.9 per cent of the increase in agricultural output can be attributed to the HRS. The jump in agricultural production mitigated the shortage of urban supply and gradually laid the foundations for the abolition of the rationing system in the early 1990s.

In the same period, the nominal average income of farm households increased by 166 per cent. The number of rural residents living in absolute poverty dropped from 250 million to 128 million, with the poverty line rising from RMB100 to RMB200 (Cai 2015a: 4).

Figure 1.3 presents the data as to how the share of the population in poverty has been falling consistently through the reform period.

Similar reforms on a different timetable and with greater difficulty were implemented in urban areas. A system of bonuses for employees was introduced in SOEs in 1978, which aimed to align incentives for employees with enterprise performance. This was followed by the state granting autonomy to and sharing profits with enterprises. 


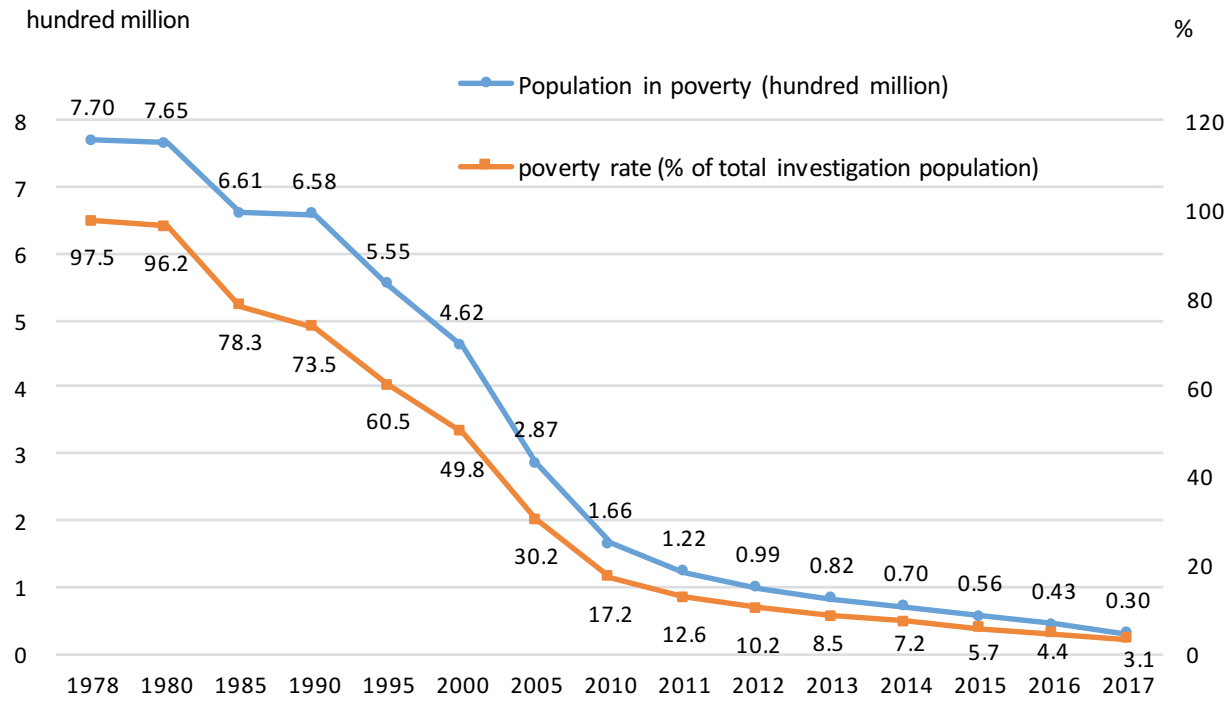

Figure 1.3 China's poverty population (hundred million), 1978-2017

Sources: State Council Information Office (2016); National Bureau of Statistics (NBS various years).

SOE reform as the core of urban reform has had several threads (Garnaut et al. 2006). One related to making SOEs viable market players, and began with the expansion of enterprises' autonomy, building up to corporatisation. Granting autonomy to enterprises began with pilot programs in some cities in the late 1970s. It was quickly extended to more regions, and then to the whole country in the early 1980s. Simplification of government controls on enterprises and delegation of authority followed through the 1980s. SOEs achieved management autonomy on setting wages and bonuses, hiring and firing workers, purchasing and selling goods and services, pricing products and utilising their own cash flows for investment.

Experiments were conducted with a variety of management forms, including managers' responsibility, enterprise contracts, asset leasing and shareholding systems. In the late 1990s, a more radical measure was introduced: 'grasping the large, letting go of the small'. This involved corporatising large SOEs based on modern enterprise management principles and privatising small and medium-sized enterprises.

A second thread involved redefining the relationship between SOEs and government. Early reform in this area featured the state sharing profits with enterprises through a host of measures aimed at introducing market discipline and accountability.

In 1988, the State Council established the State-owned Assets Administration Bureau, which was renamed the State-owned Assets Supervision and Administration Commission (SASAC) in 2003. SASAC, on behalf of the state, is 
responsible for supervising the central government's nonfinancial state enterprises. Similar organisations were established at the local level to supervise state assets owned by local governments.

The third thread was the introduction and then encouragement of nonstate enterprises (Garnaut et al. 2001). Property rights and governance structures were reformed to allow a wider range of nonstate enterprises. Competition between enterprises with different kinds of ownership and the introduction of mixed ownership of enterprises helped to increase the efficiency of SOEs.

There is now considerable competition between enterprises with different forms of ownership. In 2015, of the revenue from businesses with annual revenue of RMB20 million or more, only 4.1 per cent was generated by those registered as SOEs. The rest was generated by enterprises with 29 other kinds of ownership, including private individuals and partnerships, limited liability corporations, foreign-funded enterprises and joint ventures between Chinese and foreign enterprises.

The gradual introduction of profit-based incentives for business units in and outside agriculture has increased the importance of getting prices right. Having prices reflect true economic value is necessary for efficient resource allocation in a market economy. Enterprise reform therefore requires effective markets for setting prices for factors of production, goods and services. Transitions in markets for capital, labour, goods and services were all achieved through a 'double-track approach'. For a while, market and state-determined prices existed alongside each other. Over time, the role of market prices expanded and that of planned prices declined.

Reforms in other areas have been, by and large, carried out around these main threads. Problems arising from the process of reform and development have been dealt with pragmatically as they have arisen.

The overall direction is for the roles of central and local governments to be gradually transformed from direct involvement in economic activities to promoting equity and broadly based development through providing basic public services. Around this general direction of change, there has been a tendency for local governments to compete fervidly with one another in pursuing growth of GDP and public revenue.

This last characteristic of entrepreneurial government, while running against the general objectives of reform, has provided powerful impetus to economic growth. It has also led to overinvolvement of government in directly allocating resources, which has impeded the role of market forces (Chu and Song 2015). Since the beginning of the second decade of the twenty-first century, the Chinese Government has asserted a stronger commitment to providing public goods, including basic education, social protection, market regulations and macroeconomic policies, rather than directly participating in business activity. 
China's opening up to the international economy has proceeded in parallel with domestic reform. China has benefited in many ways from expanding imports and exports (Figure 1.4), attracting foreign investment, investing overseas and participating in global governance. Interaction with the international economy has helped Chinese enterprises to adopt advanced technologies and management and, more generally, to become more competitive through exposure to world-class competition. It has allowed China to translate the demographic dividend into massive gains from trade.

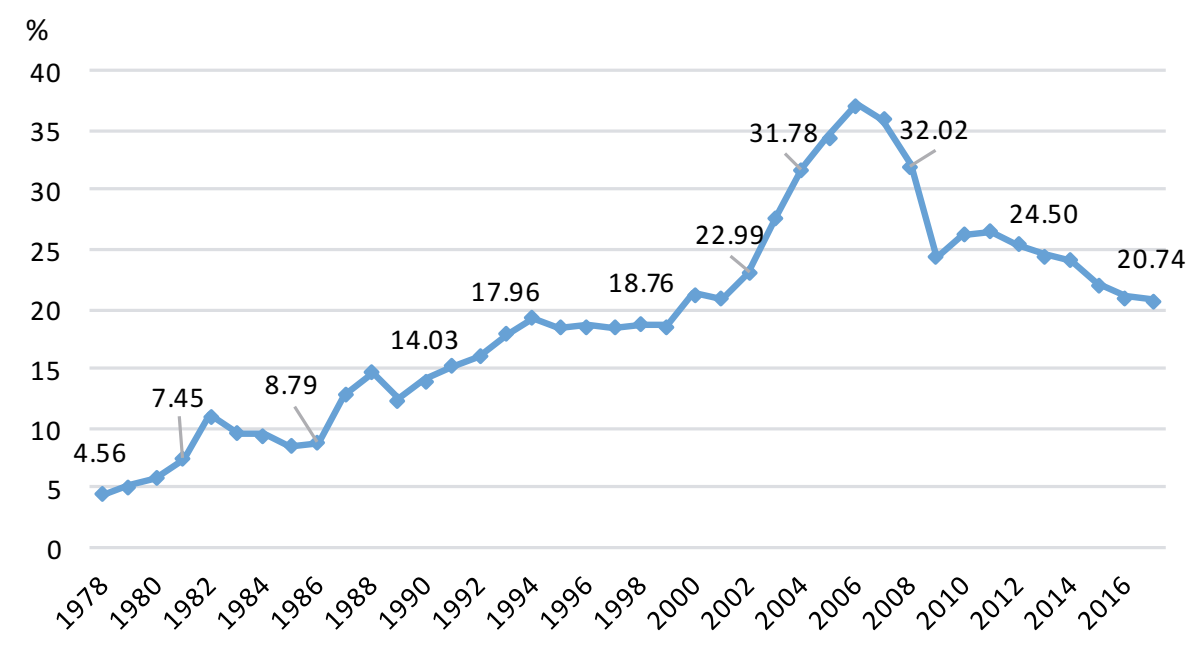

Figure 1.4 China's export share of GDP, 1978-2017

Source: IMF (2018).

\section{Impact of demographic dividend}

The demographic dividend emerges when growth in the working-age population exceeds that of the dependent population. Figure 1.5 shows that, in China, the population window of opportunity coincided with the first three-and-a-half decades of reform and opening-up. The demographic dividend began to withdraw a few years ago.

The low and declining dependency ratio, while it persisted, contributed to China's distinctive high growth rate beyond the direct influence of a high rate of growth in the labour force. It also contributed to the high savings rate. The abundant supply of labour from the countryside delays the onset of diminishing returns to capital and, by so doing, makes capital accumulation a main engine of economic growth. 


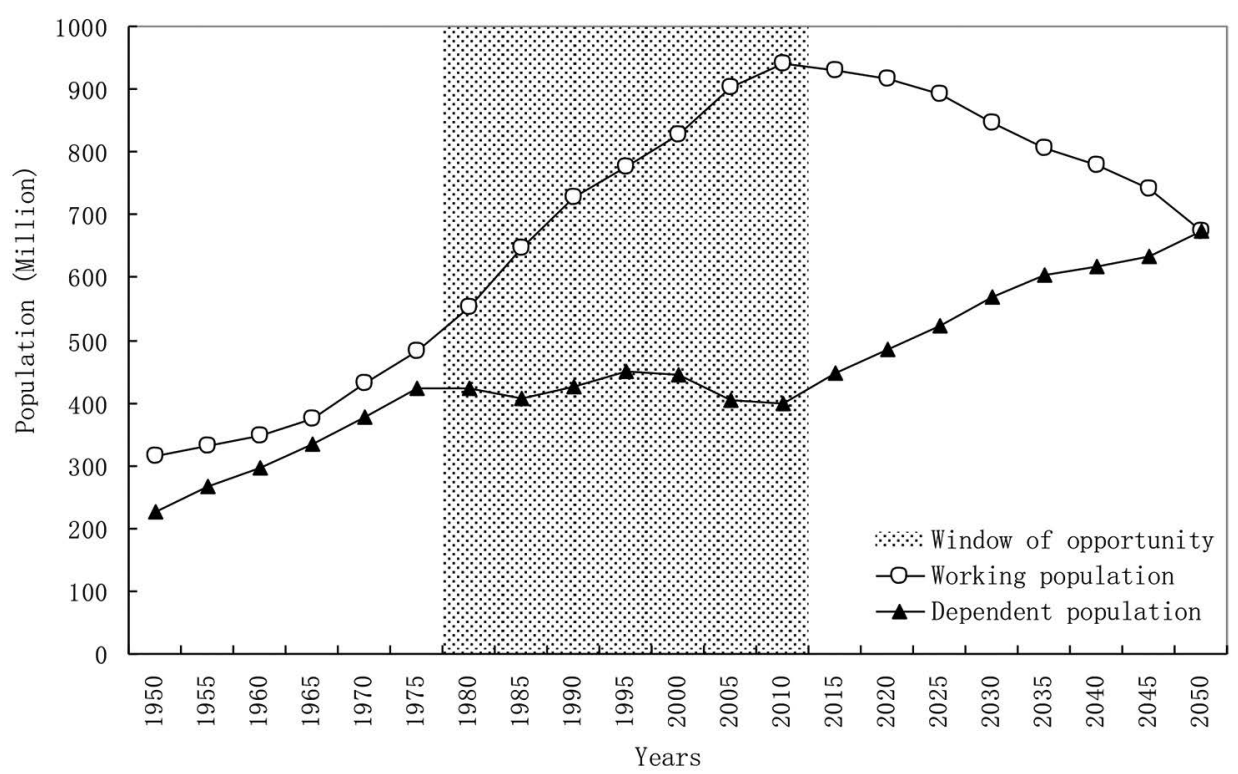

Figure 1.5 Changing trend of age structure and population window of opportunity

Source: UN DESA (2015).

Through most of China's reform period, returns to capital remained extraordinarily high (Bai et al. 2006). After the Lewis turning point characterised by labour shortage and wage inflation, ${ }^{6}$ returns to capital have rapidly diminished (Lewis 1954; Bai and Zhang 2014).

An abundant supply of labour has been widely recognised as a favourable factor for rapid growth of a developing country when it is catching up with the global frontiers. Less well understood is that improvement of human capital in the less-developed countries is greatly assisted by a favourable age structure of the population. This increases the availability of education-expressed as years of schooling-for the average new entrant to the labour market (see Cai et al. 2016).

The World Bank (1998) estimated the contribution of labour inputs to GDP growth-measured in terms of both quantity and quality-to be 17 per cent. Cai and Zhao (2012) estimated the labour contribution to be 8 per cent and human capital 4 per cent. Whalley and Zhao (2010) estimated the direct and indirect contribution of human capital to be as high as 38 per cent.

Labour mobility from lower to higher productivity uses-between rural and urban areas, among sectors and among regions-contributes significantly to TFP growth by increasing allocative efficiency. Cai (2017) found that labour productivity

6 For discussions on China's arrival at the Lewis turning point, see Cai (2015b). 
growth in the period 1978-2015 can be decomposed into 55.1 per cent from improved performance within each sector (primary, secondary and tertiary), with the balance from intersectoral movement of labour.

The World Bank (1998) divided TFP growth in China into increased intersectoral efficiency and a residual. It found that the former-namely, productivity growth resulting from labour movement from lower productivity sectors (agriculture and SOEs) to higher productivity sectors (nonagricultural sectors and newly established enterprises) — contributed 16 per cent of the GDP growth in the period 1978-95. Cai and Wang (1999) found that the labour transfer from agricultural to nonagricultural sectors constituted the majority of TFP growth and 21 per cent of per capita GDP growth in the period 1978-98 (Figure 1.6).

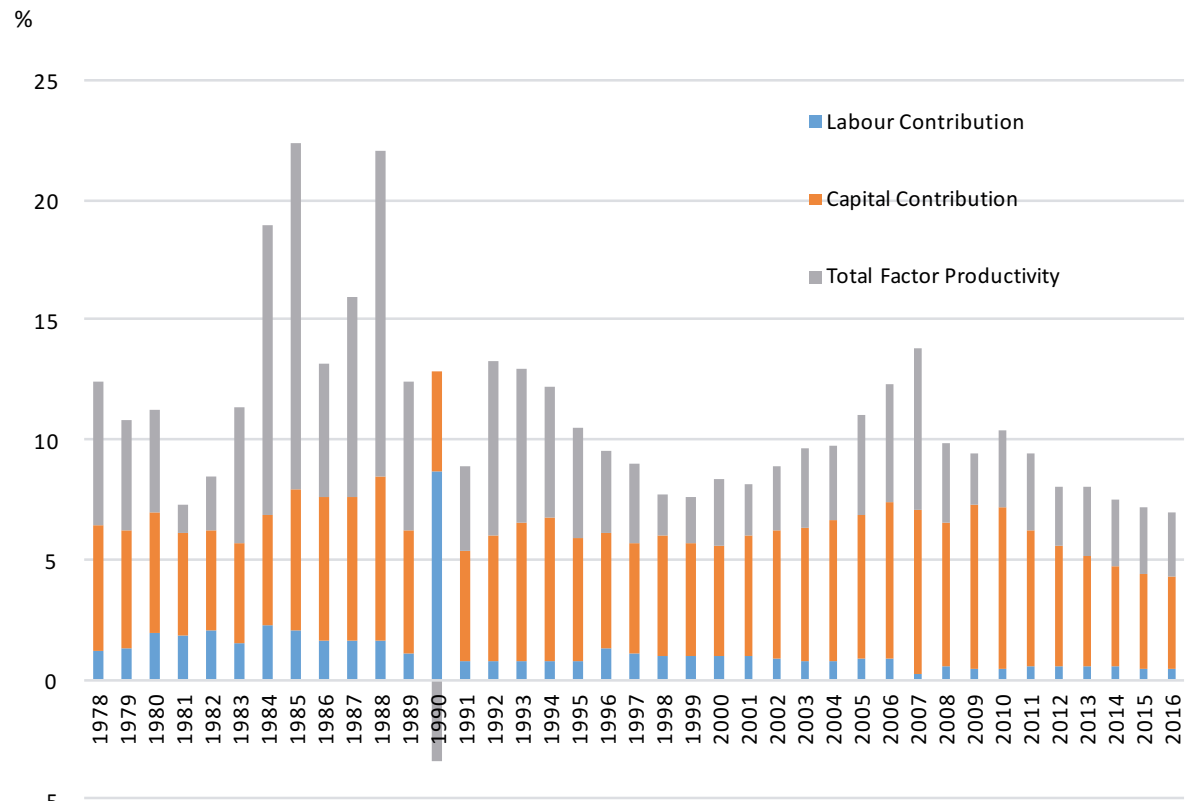

Figure 1.6 China's GDP growth decomposition, 1978-2017

Source: The Conference Board (2018).

Some scholars have taken the dependency ratio as a proxy variable to estimate the demographic dividend's contribution to China's economic growth. Wang and Mason (2008) estimated the dependency ratio contributed 15 per cent of economic growth in the period 1982-2000, while Cai and Zhao (2012) estimated it contributed 27 per cent in the same period. 
These empirical findings suggest that the outstanding performance of the Chinese economy has been the result of reform and opening-up cashing in on advantageous demographic and other underlying conditions. Cai and $\mathrm{Lu}$ (2013) estimated that the potential GDP growth rate was 9.7 per cent in the period 1979-95 and 10.4 per cent in $1997-2010$.

Cai (2017) estimated that while total employment in rural and urban areas increased from 402 million in 1978 to 775 million in 2015, the share of agricultural labour dropped from 69.6 per cent to 18.3 per cent.

Strong employment growth spreads the improvement in living standards. Despite a widening income gap in most of the reform period, three effects have helped to disperse the results of reform, opening-up and growth, and so helped to win the legitimacy of that reform and opening-up.

First is the increase in employment. The expansion of labour-intensive industries created numerous jobs outside agriculture. In the period 1978-2015, while GDP and per capita GDP in real terms increased by 29 and 20 times, respectively, real consumption of rural and urban Chinese households, on average, increased by 16 times. For many years, the improvement of people's living standards owed more to increased nonagricultural employment than to higher wages.

For example, Cai et al. (2009: 220) estimate that in the period 1997-2004 the number of migrant workers-defined as rural labourers who worked in cities for six months or longer-increased from less than 40 million to over 100 million. While there was no significant increase in the real wage rate, total wages grew at an annual rate of 14.9 per cent in real terms. As a result, the share of wages in rural households' income increased from 24.6 per cent to 34 per cent.

Second is the more recent increase in the wage rate (Garnaut and Huang 2006). Since the Chinese economy entered the Lewis turning point, or period, ${ }^{7}$ some time from 2004, the wages of ordinary workers have increased rapidly. In the period 2003-16, the average wage of migrant workers in real terms grew at a rate of 10.1 per cent. As a consequence, after 2009, the Gini coefficient of residents' income and the income gap between rural and urban households both fell steadily.

Third is the effect of redistribution policy. Coinciding with the arrival of the Lewis turning point, China's central and local governments have intensified redistributive policies. These include strengthening the poverty alleviation program in rural areas, expanding the coverage and equalising the provision of public services, raising mandatory minimum wages and relaxing household registration control over population migration (Cai 2016).

7 Garnaut (2013) has noted that in China, as a large and differentiated country, the Lewis turning point would not come at a single point in time, but emerge through the economy over a period. 


\section{New development stage and unfinished tasks}

In the past 40 years, China has gone a long way towards two important systemic transitions-from a planned to a market economy, and from a dual economy to neoclassical growth. China has also undergone a rapid demographic transition, from high to low fertility.

Economic reform and opening-up to the world economy have created an institutional environment in which a demographic dividend has been translated into extraordinary economic growth (Table 1.1). Reforms of incentive mechanisms, enterprise governance, price determination, resource allocation systems, foreign trade and investment and the macropolicy environment have contributed differently at each stage of development.

Table 1.1 Summary of growth sources and their trends

\begin{tabular}{|c|c|c|}
\hline Growth factors & How they worked & Features and implications \\
\hline $\begin{array}{l}\text { Capital } \\
\text { accumulation }\end{array}$ & $\begin{array}{l}\text { Low dependency ratio conducive to } \\
\text { high savings; unlimited supply of labour } \\
\text { prevents diminishing return on capital }\end{array}$ & $\begin{array}{l}\text { Unsustainable; as labour becomes } \\
\text { scarce, return on capital begins } \\
\text { diminishing }\end{array}$ \\
\hline $\begin{array}{l}\text { Quantity of } \\
\text { labour }\end{array}$ & $\begin{array}{l}\text { Population structure guarantees labour } \\
\text { supply, which turns into comparative } \\
\text { advantage in labour-intensive } \\
\text { manufacturing }\end{array}$ & $\begin{array}{l}\text { Unsustainable; demographic dividend } \\
\text { disappears as economy passes Lewis } \\
\text { turning point }\end{array}$ \\
\hline Human capital & $\begin{array}{l}\text { Education expansion and mass labour } \\
\text { entry improves quality of stock of } \\
\text { workers }\end{array}$ & $\begin{array}{l}\text { Education expansion eventually slows, } \\
\text { calling for enhancing its quality and } \\
\text { equality }\end{array}$ \\
\hline TFP & $\begin{array}{l}\text { Increase from improvement of incentives } \\
\text { and resource allocation system }\end{array}$ & $\begin{array}{l}\text { Increasingly challenging and important } \\
\text { to sustain growth; requires new } \\
\text { sources of increase }\end{array}$ \\
\hline $\begin{array}{l}\text { TFP, of which: } \\
\text { resource } \\
\text { reallocation }\end{array}$ & $\begin{array}{l}\text { Reallocative efficiency of resources } \\
\text { through labour mobility from agriculture } \\
\text { to industrial sectors }\end{array}$ & $\begin{array}{l}\text { Dominant in early stage of } \\
\text { development; diminishes after Lewis } \\
\text { turning point }\end{array}$ \\
\hline $\begin{array}{l}\text { TFP, of which: } \\
\text { technology }\end{array}$ & $\begin{array}{l}\text { Utilisation of advantage of } \\
\text { backwardness through absorbing } \\
\text { foreign technology and management }\end{array}$ & $\begin{array}{l}\text { As gap narrows, technological } \\
\text { progress increasingly relies on } \\
\text { independent innovation }\end{array}$ \\
\hline Population factor & $\begin{array}{l}\text { Widely defined demographic dividend } \\
\text { is manifested in all factors driving rapid } \\
\text { growth }\end{array}$ & $\begin{array}{l}\text { Diminishes as China ages; second } \\
\text { dividend available from removing } \\
\text { remaining barriers to movement }\end{array}$ \\
\hline
\end{tabular}

Source: Authors' summary.

For a certain period, investment and net exports rather than consumption contributed disproportionately to economic growth in China (Figure 1.7). Sustaining strong growth now requires consumption to play a more important role in driving expansion of the economy. Progress has been made in recent years: increases in total household and government consumption now exceed increases in investment (Figure 1.8). 


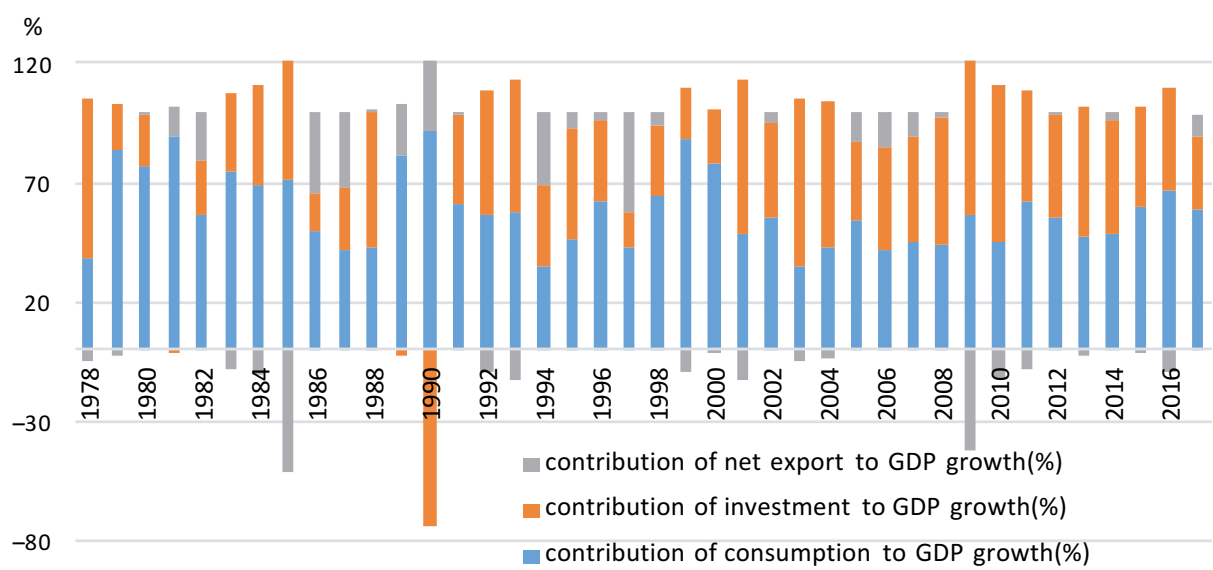

Figure 1.7 Contribution of consumption, investment and exports to China's GDP growth, 1978-2017

Source: NBS (various years).

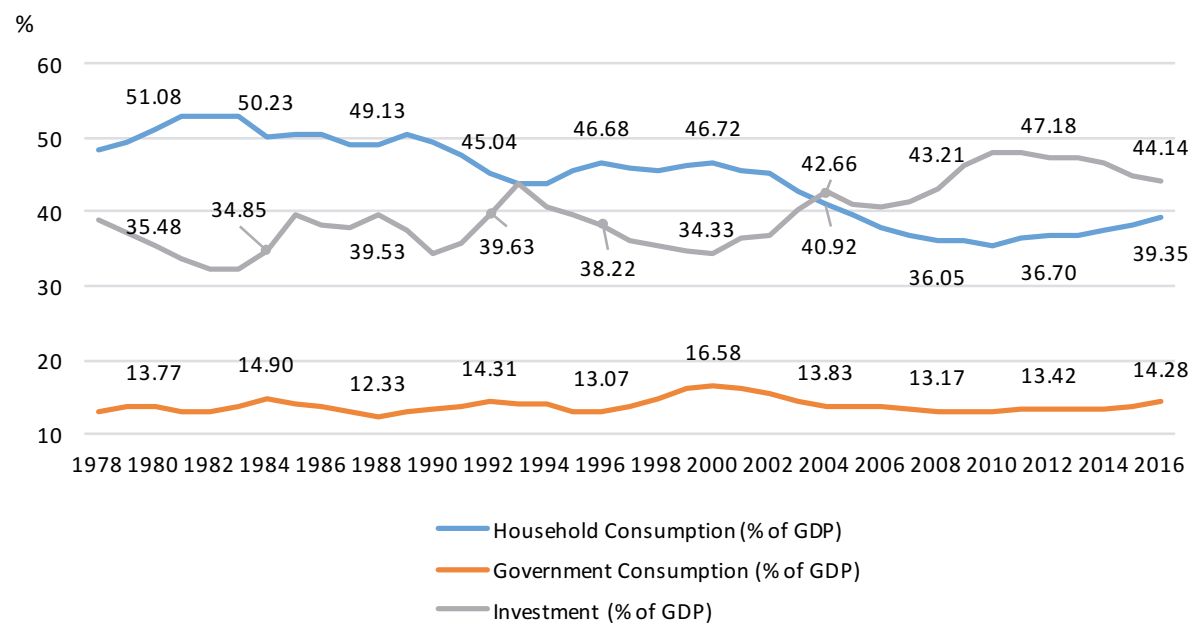

Figure 1.8 China's consumption and investment share of GDP, 1978-2017 Source: NBS (various years).

If China is to graduate from upper-middle-income to high-income status, its growth needs to shift from reliance on increases in labour and capital supply to reliance on productivity enhancement. This requires more effective markets-and reforms that are inherently difficult.

As summarised in Table 1.1, after the Chinese economy entered the Lewis turning point-characterised by a labour shortage and rising wages-the demographic dividend diminished rapidly. All of the elements that drove rapid growth in the first quarter-century of reform became weaker. The potential growth rate was bound to 
decline. A labour shortage means that wages grow faster than productivity. The rapid increase in the capital-labour ratio leads to a sharp decline in return to investment. The shrinkage of new entrants to the labour market slows the improvement of human capital. The deceleration of labour movement from agriculture to other sectors removes a source of rapid improvement in allocative efficiency, leading to a sharp fall in TFP growth.

All of these considerations lower China's potential growth rate by a considerable amount.

Cai and Lu (2013) estimate that China's potential growth rate has fallen from about 10 per cent per annum prior to 2010 to 7.6 per cent in the period of the twelfth five-year plan (2011-15) and 6.2 per cent in the thirteenth five-year-plan period (2016-20). Nevertheless, Cai and Lu (2016) suggest that the decline of China's potential growth rate will be smooth and slow and, until 2050, will remain higher than 3 per cent. The slowdown in the actual growth rate has so far followed this trajectory.

Growth theories and the lessons of experience show us that growth slows in the transition from dual-economy development with potential for catching-up with advanced economies to neoclassical growth at the global technological frontier (Eichengreen et al. 2013; Barro 2016). However, the pace at which potential growth falls and the extent to which it deviates from the potential growth rate differ across countries (Eichengreen et al. 2011).

China will not be exempt from the iron law of regression to the mean in the long run (Pritchett and Summers 2014). However, by deepening reform and upgrading its industrial structure, China can prevent its potential growth rate from falling too fast, find its way out of the 'middle-income trap' and accomplish its goal of modernisation.

Deeper reform is essential to spur on future economic growth. The difference between reform and status quo outcomes is dramatically large (Cheremukhim et al. 2015).

One reason the maintenance of productivity growth through deeper reform is now more difficult than in earlier decades is that it is now harder to find improvements that benefit one substantial group in society without hurting others. It is harder now to find Pareto improvements of the kind associated with the introduction of the HRS.

This raises new challenges. First, reform now faces resistance and interference from vested interests. Second, in the course of the 'creative destruction' necessary for tapping new sources of growth, some workers will lose established jobs and some enterprises will disappear. There will be perceptions of a public interest case 
for slowing reform - the product of what Corden (1974) called the conservative social welfare function. To meet those challenges, the reform dividend - the added economic value from new reform measures — should be made available to the losers of reform. This converts a Pareto improvement into a Kaldor-Hicks improvement (Scitovsky 1941). ${ }^{8}$

Successful reform to maintain growth in these circumstances requires political wisdom and determination. The required policy measures include redefining fiscal expenditure responsibilities between central and local governments, strengthening social protection for unemployed workers and disadvantaged families and more generally compensating the losers from reform.

There is some opportunity for allocative gains from moving people from agricultural and other rural employment into employment with higher productivity in the towns, through removing artificial barriers to relocation. This, too, faces resistance from established urban residents. Again, wisdom and determination from government are required to unlock a reform dividend.

Future TFP growth will have to come, to a considerable extent, from innovation, involving Schumpeterian 'creative destruction'. Studies suggest that in developed countries, allocative efficiency relating to the entry, expansion, contraction and exit of firms within narrowly defined sectors can contribute one-third to one-half of national productivity growth (Foster et al. 2008). To make such a mechanism work in China requires deepening reforms to increase competition, break monopolies, encourage entrepreneurial activities and strengthen social protection.

The road ahead will be harder in some important respects than the road already travelled. The difference between continuing along the road and staying still is the difference between China joining the ranks of the high-income countries and being caught in a middle-income trap (Armstrong and Westland 2016).

\section{References}

Armstrong, S. and Westland, T. (2016), Escaping the middle income trap: Trade, investment and innovation, in F. Hutchinson and S. Basu Das (eds), Asia and the Middle Income Trap, Oxford: Routledge.

Bai, C.-E. and Zhang, Q. (2014), The rates of return to capital and the analysis of the determinants, The World Economy (10): 3-30.

8 A 'Kaldor improvement' refers to a change in which the total gains outweigh the total losses so that it is possible for beneficiaries-perhaps through government-to compensate nonbeneficiaries for the losses they suffer. As a result, no one suffers in the end. See Kaldor (1939). 
Bai, C.-E., Hsieh, C.-T. and Qian, Y. (2006), The return to capital in China, NBER Working Paper No. 12755, Cambridge, MA: National Bureau of Economic Research.

Barro, R. J. (2016), Economic growth and convergence, applied especially to China, NBER Working Paper No. 21872, Cambridge, MA: National Bureau of Economic Research.

Brandt, L., Ma, D. and Rawski, T. G. (2014), From divergence to convergence: Reevaluating the history behind China's economic boom, Journal of Economic Literature 52(1): 45-123. doi.org/10.1257/jel.52.1.45.

Cai, F. (ed.) (2010), Transforming the Chinese Economy, 1978-2008, Leiden: Brill.

Cai, F. (2015a), Demystifying China's Economic Development, Beijing and Berlin: China Social Sciences Press and Springer-Verlag. doi.org/10.1007/978-3-66246103-7.

Cai, F. (2015b), The making of dual economy as a stage of economic development, Economic Research Journal (7): 4-15.

Cai, F. (2016), China's Economic Growth Prospects: From demographic dividend to reform dividend, Cheltenham, UK: Edward Elgar.

Cai, F. (2017), Reform effects in China: A perspective of labor reallocation, Economic Research Journal (7): 4-17.

Cai, F. and Lu, Y. (2013), The end of China's demographic dividend: The perspective of potential GDP growth, in R. Garnaut, F. Cai and L. Song (eds), China: A new model for growth and development, Canberra: ANU E Press.

Cai, F. and Lu, Y. (2016), Take-off, persistence, and sustainability: The demographic factor in Chinese growth, Asia o the Pacific Policy Studies 3(2): 203-25. doi.org/ 10.1002/app5.139.

Cai, F. and Wang, D. (1999), The sustainability of economic growth and the labor contribution, Economic Research Journal (10): 62-8.

Cai, F. and Zhao, W. (2012), When demographic dividend disappears: Growth sustainability of China, in M. Aoki and J. Wu (eds), The Chinese Economy: A new transition, Basingstoke, UK: Palgrave Macmillan.

Cai, F., Du, Y., Gao, W. and Wang, M. (2009), Labor Economics: Theories and Chinese experiences, Beijing: Beijing Normal University Publishing Group. 
Cai, F., Guo, Z. and Wang, M. (2016), New urbanisation as a driver of China's growth, in L. Song, R. Garnaut, F. Cai and L. Johnston (eds), China's New Sources of Economic Growth. Volume 1: Reform, resources and climate change, Canberra: ANU Press. doi.org/10.22459/CNSEG.07.2016.03.

Cheremukhim, A., Golosov, M., Guriev, S. and Tsyvinski, A. (2015), The economy of People's Republic of China from 1953, NBER Working Paper No. 21397, Cambridge, MA: National Bureau of Economic Research.

Chu, S. N. and Song, L. (2015), Promoting private entrepreneurship for deepening market reform in China: A resource allocation perspective, China \& World Economy 23(1): 47-77. doi.org/10.1111/cwe.12099.

The Conference Board (2018), Total Economy Database, April, New York: The Conference Board. Available from: www.conference-board.org/data/ economydatabase/.

Corden, W. M. (1974), Trade and Welfare, Oxford: Oxford University Press.

Eichengreen, B., Park, D. and Shin, K. (2011), When fast growing economies slow down: International evidence and implications for China, NBER Working Paper No. 16919, Cambridge, MA: National Bureau of Economic Research.

Eichengreen, B., Park, D. and Shin, K. (2013), Growth slowdowns redux: New evidence on the middle-income trap, NBER Working Paper No. 18673, Cambridge, MA: National Bureau of Economic Research.

Foster, L., Haltiwanger, J. and Syverson, C. (2008), Reallocation, firm turnover, and efficiency: Selection on productivity or profitability?, American Economic Review 98(1): 394-425. doi.org/10.1257/aer.98.1.394.

Garnaut, R. (2013), Macro-economic implications of the turning point, in Y. Huang and F. Cai (eds), Debating the Lewis Turning Point in China, Routledge: London.

Garnaut, R. and Huang, Y. (2006), Continued rapid economic growth and the turning point in economic development, in R. Garnaut and L. Song (eds), The Turning Point in China's Economic Development, Canberra: Asia Pacific Press. doi.org/10.26530/OAPEN_459745.

Garnaut, R. and Song, L. (eds) (2006), The Turning Point in China's Economic Development, Canberra: Asia Pacific Press. doi.org/10.26530/OAPEN_459745.

Garnaut, R., Song, L. and Yao, Y. (2006), Impact and significance of state-owned enterprise restructuring in China, The China Journal (55): 35-63.

Garnaut, R., Song, L., Yao Y. and Wang, X. (2001), Private Enterprise in China, Canberra: Asia Pacific Press. 
International Monetary Fund (IMF) (2006), Asia rising: Patterns of economic development and growth, in World Economic Outlook, September, Washington, DC: IMF.

International Monetary Fund (IMF) (2018), Global economic outlook 2018 dataset. Available from: www.imf.org/external/datamapper/NGDP_RPCH@ WEO/OEMDC/ADVEC/WEOWORLD.

Jin, P. (ed.) (2005), The Quotations by Confucius, Beijing: China Federation of Literary and Art Circles Publishing House.

Kaldor, N. (1939), Welfare propositions of economics and interpersonal comparisons of utility, Economic Journal 49(September): 549-51. doi.org/10.2307/2224835.

Kwan, Y. and Chow, G. (1996), Estimating economic effects of political movements in China, Journal of Comparative Economics 23(2): 192-208. doi.org/10.1006/ jcec. 1996.0054 .

Lewis, A. (1954), Economic development with unlimited supplies of labor, The Manchester School 22(2): 139-91. doi.org/10.1111/j.1467-9957.1954. tb00021.x.

Lin, J. Y. (1992), Rural reforms and agricultural growth in China, American Economic Review 82(1): 34-51.

Lin, J. Y., Cai, F. and Li, Z. (2003), The China Miracle: Development strategy and economic reform, rev. edn, Hong Kong: The Chinese University Press.

Lin, J. Y. and Wang, Y. (2010), China's integration with the world: Development as a process of learning and industrial upgrading, in F. Cai (ed.), Transforming the Chinese Economy, 1978-2008, Leiden and Boston: Brill.

Maddison, A. (2007), Chinese Economic Performance in the Long Run, 960-2030 $A D$, 2nd edn, Paris: OECD Publishing.

National Bureau of Statistics (NBS) (various years), China Statistical Yearbook, Beijing: China Statistics Press.

Pritchett, L. and Summers, L. H. (2014), Asiaphoria meets regression to the mean, NBER Working Paper No. 20573, Cambridge, MA: National Bureau of Economic Research.

Scitovsky, T. (1941), A note on welfare proposition in economics, The Review of Economic Studies 9(1): 77-88. doi.org/10.2307/2967640.

Spence, M. (2011), The Next Convergence: The future of economic growth in a multispeed world, New York: Farrar, Straus and Giroux. 
State Council Information Office (2016), China's progress in poverty reduction and human rights development, [in Chinese], White Paper, 17 October, Beijing: State Council Information Office. Available from: www.scio.gov.cn/tt/zdgz/ Document/1494216/1494216.htm.

United Nations Department of Economic and Social Affairs (UN DESA) (2015), World Population Prospects: The 2015 revision, DVD edn, New York: Population Division, UN DESA.

Wang, F. and Mason, A. (2008), The demographic factor in China's transition, in L. Brandt and T. G. Rawski (eds), China's Great Economic Transformation, Cambridge: Cambridge University Press.

Whalley, J. and Zhao, X. (2010), The contribution of human capital to China's economic growth, NBER Working Paper No. 16592, Cambridge, MA: National Bureau of Economic Research.

World Bank (1998), China 2020: Development challenges in the new century, Oxford: Oxford University Press.

Zhu, X. (2012), Understanding China's growth: Past, present, and future, Journal of Economic Perspectives 26(4): 103-24. doi.org/10.1257/jep.26.4.103. 
This text is taken from China's 40 Years of Reform and Development: 1978-2018, edited by Ross Garnaut, Ligang Song and Cai Fang, published 2018 by ANU Press, The Australian National University, Canberra, Australia.

doi.org/10.22459/CYRD.07.2018.01 